\title{
Korelasi antara Sikap Ilmiah dalam Belajar dengan Kompetensi Inti Pengetahuan IPA
}

\author{
Pt. Suryantini1 ${ }^{*}$, I Wyn.Sujana², I Wyn. Wiarta ${ }^{3}$ \\ 1 Jurusan PGSD Universitas Pendidikan Ganesha Singaraja, Indonesia \\ 2 Jurusan PGSD Universitas Pendidikan Ganesha Singaraja, Indonesia \\ 3 Jurusan PGSD Universitas Pendidikan Ganesha Singaraja, Indonesia
}

\begin{abstract}
Abstrak
Penelitian ini bertujuan untuk mengetahui korelasi yang signifikan antara sikap ilmiah dalam belajar dengan kompetensi inti pengetahuan IPA siswa kelas V SD Gugus Kapten Kompyang Sujana Denpasar Barat Tahun Pelajaran 2017/2018.Jenis penelitian ini adalah penelitian ex post facto dengan korelasi yang bersifat asimetris.Populasi penelitian ini adalah siswa kelas V SD Gugus Kapten Kompyang Sujana, Denpasar Barat Tahun Pelajaran yang berjumlah 637 orang. Penentuan sampel menggunakan teknik proporsional random sampling dengan taraf signifikansi $5 \%$ dan diperoleh banyak sampel dari populasi adalah 227 orang. Data kompetensi inti pengetahuan IPA diperoleh dari pencatatan dokumen dan sikap ilmiah dalam belajar diperoleh dengan menggunakan kuesioner. Sebagai uji persyarat adalah uji normalitas sebaran data.Selanjutnya data dianalisis dengan korelasi product moment. Berdasarkan hasil analisis maka $r_{-}(x y$ hitung) diperoleh sebesar 0,202 dan untuk $\mathrm{n}=$ 227 pada taraf signifikansi 5\%, maka diperoleh $r_{-}$(xy tabel) sebesar 0,138 sebagai pembanding. Karena $r_{-}(x y$ hitung $)>r_{-}(x y$ tabel $)=0,202>0,138$ maka dapat diartikan bahwa H_0 yang berbunyi tidak terdapat korelasi yang signifikan antara sikap ilmiah dalam belajar dengan kompetensi inti pengetahuan IPA siswa kelas V SD Gugus Kapten Kompyang Sujana Denpasar Barat Tahun Pelajaran 2017/2018 ditolak. Jadi dapat disimpulkan bahwa terdapat korelasi yang signifikan antara sikap ilmiah dalam belajar dengan kompetensi inti pengetahuan IPA siswa kelas V SD Gugus Kapten Kompyang Sujana Denpasar Barat Tahun Pelajaran 2017/2018, dengan arah korelasi positif, artinya semakin tinggi sikap ilmiah siswa dalam belajar maka semakin tinggi pula kompetensi inti pengetahuan IPA yang diperoleh siswa.
\end{abstract}

\author{
Keywords: \\ sikap ilmiah, belajar, \\ kompetensi inti \\ pengetahuan IPA
}

\section{PENDAHULUAN}

Kurikulum merupakan suatu alat yang penting bagi pencapaian keberhasilan pendidikan.Tanpa adanya kurikulum yang tepat dan sesuai, maka tujuan pendidikan sulit dicapai.Kurikulum yang digunakan di kota Denpasar saat ini yaitu kurikulum 2013. Pembelajaran dalam Kurikulum 2013 bukanlah pembelajaran yang berpusat pada guru, melainkan pembelajaran harus berpusat pada siswa.Adanya perubahan tersebut, diharapkan dapat mendorong siswa untuk terlibat secara aktif dalam membangun pengetahuan, sikap, dan keterampilan.Pembelajaran yang berpusat pada siswa sangat bermanfaat untuk siswa sendiri dikarenakan dapat membangun pengetahuannya, sehingga siswa mendapatkan pemahaman yang mendalam.Hal tersebut dapat meningkatkan hasil belajar siswa.

Setelah kegiatan pembelajaran, siswa mengetahui tingkat keberhasilannya dalam belajar. Hasil belajar tidak langsung terlihat saat siswa mengikuti proses belajar, melainkan setelah melalui kegiatan belajar. "Penilaian hasil belajar siswa mencakup segala hal yang dipelajari di sekolah, baik itu menyangkut pengetahuan, sikap, dan keterampilan yang berkaitan dengan mata pelajaran yang diberikan kepada siswa" (Susanto, 2015:6).Hasil belajar siswa dapat dilihat dari pencapaian kompetensi setelah melalui kegiatan pembelajaran. Hasil belajar yang langsung didapat setelah proses pembelajaran berlangsung yaitu kompetensi inti pengetahuan. Belajar merupakan kegiatan penting yang harus dilakukan oleh siswa.Belajar sangat bermanfaat bagi siswa karena dengan belajar siswa memperoleh ilmu dan mengalami perubahan-perubahan. 
Banyak faktor yang mempengaruhi hasil belajar siswa. Menurut Slameto (2010:188) "faktor lain yang mempengaruhi hasil belajar siswa adalah sikap". Pada penelitian Suryani (2016:Vol. 3) mengatakan bahwa "sikap ilmiah merupakan salah satu faktor dalam diri individu yang mempengaruhi belajar siswa". Idealnya sikap ilmiah juga memberikan pengaruh terhadap hasil belajar siswa.Menurut Samatowa (2011:97) mengatakan "sikap ilmiah ini perlu dikembangkan lebih lanjut sesuai dengan karakteristik mata pelajaran sains di Sekolah Dasar".Sikap ilmiah biasanya dikembangkan pada mata pelajaran IPA.IPA merupakan salah satu mata pelajaran yang ada di Sekolah. Mata pelajaran IPA tidak hanya diperoleh saat duduk dibangku SD saja, namun sampai sekolah menengah atas. Badan Standar Nasional Pendidikan (2006) menyatakan Ilmu Pengetahuan Alam (IPA) berhubungan dengan cara mencari tahu tentang alam secara sistematis, sehingga IPA bukan hanya penguasaan kumpulan pengetahuan yang berupa fakta-fakta saja tetapi juga merupakan suatu penemuan. Menurut Bundu (2006) mata pelajaran IPA memiliki tiga komponen utama yang berkaitan erat, yaitu proses ilmiah, produk ilmiah dan sikap ilmiah.Aspek pokok dalam mata pelajaran IPA yaitu siswa memiliki rasa ingin tahu untuk memperoleh pengetahuannya sendiri, sehingga dapat mengaplikasikan ke dalam kehidupan sehari-hari.Mata pelajaran IPA di SD hendaknya dapat memberikan kesempatan kepada siswa untuk memupuk rasa ingin tahu siswa sehingga dapat mengembangkan cara berpikir ilmiah Hal ini tentunya harus ditunjang dengan mengembangkan dan menumbuhkan sikap ilmiah siswa.

Sikap ilmiah siswa dalam belajar sangat diperlukan dalam mata pelajaran IPA.Hal tersebut dikarena sikap ilmiah dapat menghindari munculnya sikap negatif dalam diri siswa.Sikap negatif tersebut seperti tidak jujur dan selalu rendah diri dimana siswa selalu merasa dirinya gagal sebelum melakukan tugas.Sikap ilmiah adalah sikap dalam diri siswa yang tidak dapat diajarkan melalui satuan pembelajaran tertentu yang harus terus dikembangkan dalam menghadapi suatu objek untuk mendapatkan suatu ilmu pengetahuan yang berorientasi pada metode ilmiah.

Sikap ilmiah sangat diperlukan siswa dalam proses mata pelajaran IPA karena dapat memotivasi siswa dalam kegiatan pembelajaran. Sikap ilmiah dapat memberikan dampak yang positif terhadap siswa. Pada penelitian Sugiartana (2013:Vol. 1) mengatakan bahwa "kurangnya sikap positif siswa dalam belajar dapat menyebabkan rendahnya hasil belajar siswa". Hal ini tentunya sangat memengaruhi hasil dari kegiatan belajar siswa.Melalui penanaman dan pengembangan sikap ilmiah siswa memiliki kemungkinan untuk lebih dapat belajar memahami dan menemukan suatu ilmu pengetahuan. Selain itu pada penelitian Harso (2014:Vol. 4) menerangkan bahwa "siswa yang memiliki sikap ilmiah yang tinggi akan memiliki kelancaran dalam berpikir sehingga akan termotivasi untuk selalu berprestasi dan memiliki komitmen yang kuat untuk mencapai keberhasilan dan keunggulan".

Realita yang terjadi di lapangan, sikap ilmiah siswa SD belum optimal dikembangkan dalam diri siswa. Hal tersebut dikarenakan dalam memberikan contoh sikap ilmiah, guru hanya memberikan contoh pada saat menghargai pendapat siswa, memberikan penguatan positif dengan pernyataan verbal seperti mengucapkan "baik" dan guru jarang melakukan diskusi kelompok serta percobaan.

Berdasarkan uraian tersebut, salah satu yang menunjang kompetensi inti pengetahuan IPA siswa adalah sikap ilmiah dalam belajar.Siswa yang mempunyai sikap ilmiah yang tinggi membuat siswa aktif dalam belajar sehingga dapat mempermudah siswa dalam menerima dan memahami materi mata pelajaran IPA. Tujuan yang ingin dicapai dalam penelitian ini adalah untuk mengetahui korelasi yang signifikan antara sikap ilmiah dalam belajar dengan kompetensi inti pengetahuan IPA siswa kelas V SD Gugus Kapten Kompyang Sujana Denpasar Barat Tahun Pelajaran 2017/2018

\section{METODE PENELITIAN}

Jenis penelitian ini adalah peneliian ex post facto dengan studi korelasional.Penelitian ini dilaksanakan pada semester 2 siswa kelas V SD Gugus Kapten Kompyang Sujana Denpasar Barat Tahun Pelajaran 2017/2018 yang terdiri dari 7 sekolah negeri dan 1 sekolah swasta. SD yang dipergunakan dalam penelitian ini yaitu seluruh sekolah negeri di SD Gugus Kompyang Sujana.Letak masing-masing SD di Gugus Kapten Kompyang Sujana cukup berdekatan.Ketujuh sekolah yaitu SD Negeri 1 Padangsambian, SD Negeri 2 Padangsambian, SD Negeri 8 Padangsambian, SD Negeri 9 Padangsambian, SD Negeri 10 Padangsambian, SD Negeri 12 Padangsambian dan SD Negeri 14 Padangsambian.

Dalam penentuan sampel dapat dilihat pada tabel Issac and Michael.Dalam tabel tersebut dijelaskan tentang besarnya sampel yang diambil darig populasi dengan tingkat signifikansi $1 \%, 5 \%$, dan $10 \%$. Sesuai dengan tabel tersebut, jumlah populasi di SD Gugus Kapten Kompyang Sujana Denpasar Barat sebanyak 637 siswa, sedangkan populasi yang ada dalam tabel Issac and Michael yang mendekati jumlah populasi di SD Gugus Kapten Kompyang Sujana Denpasar Barat adalah 650 orang, jadi jumlah sampel yang diambil dengan tingkat signifikansi $5 \%$ adalah 227 orang. 
Kesimpulannnya pada penelitian ini menggunakan populasi 637 siswa dan sampel 110 siswa.Pengambilan sampel menggunakan proporsional random sampling.Cara penentuan sampel secara random dalam penelitian ini dilakukan dengan menggunakan undian nomor absen siswa.Nomor absen siswa ditulis pada secarik kertas, kemudian digulung, diundi seperti pengundian arisan.

Variabel bebas yang ditetapkan dalam penelitian ini adalah sikap ilmiah dalam belajar, sedangkan variabel terikat dalam variabel ini adalah kompetensi inti pengetahuan IPA. Pengumpulan data dalam penelitian ini meliputi: (1) sikap ilmiah dalam belajar, dan (2) kompetensi inti pengetahuan IPA. Data sikap ilmiah dalam belajar dikumpukan menggunakan kuesioner. Kuesioner tersebut terdapat pernyataan dengan masing-masing 4 pilihan yaitu Sangat Setuju (SS), Setuju (S), Tidak Setuju (TS) dan Sangat Tidak Setuju (STS). Pernyataan yang terdapat pada kuesioner sebanyak 25 pernyataan. Pernyataan positif memiliki skor 4 untuk sangat setuju, skor 3 untuk setuju, skor 2 untuk tidak setuju dan skor 1 untuk sangat tidak setuju. Sedangkan pada pernyataan negatif skor 4 untuk sangat tidak setuju, skor 3 untuk tidak setuju, skor 2 untuk setuju dan skor 1 untuk sangat setuju.Data kompetensi inti pengetahuan IPA diperoleh dengan pencatatan dokumen.Data yang dikumpulkan melalui pencatatan dokumen adalah nilai ulangan harian IPA tema 7 siswa kelas V SD Gugus Kapten Kompyang Sujana Denpasar Barat Tahun Pelajaran 2017/2018.

Pengujian instrumen sikap ilmiah dalam belajar yaitu menggunakan uji validitas diantaranya validitas isi dan konstrak.Uji validitas isi dilakukan dengan cara menyesuaikan butir tes dengan indikator. Uji validitas isi ini dilakukan dengan membuat kisi-kisi pernyataan.Menguji validitas konstrak, dapat digunakan pendapat dari para ahli (judgment experts).Setelah instrument dikonstruksi tentang aspekaspek yang diukur dengan dilandaskan teori tertentu, hasil tersebut dikonstruksikan kepada para ahli. Setelah melalui proses review oleh ahli, instrumen mengalami perbaikan sesuai saran ahli.

Teknik analisis data dalam penelitian ini yaitu analisis statistik deskriptif dan analisis statistik inferensial.Analisis statistik deskriptif menggunakan rata-rata (mean), median dan standar deviasi.Sedangkan analisis statistik inferensial menggunakan teknik korelasi product moment.Sebelum menguji hipotesis, maka dilakukan uji prasyarat yaitu uji normalitas.Uji normalitas (X2) untuk mengetahui apakah data berdistribusi normal atau tidak.Hasil X2, selanjutnya dikonsultasikan ke tabel chi-square pada taraf signifikansi $5 \%$ dan derajat kebebasan $(\mathrm{dk})=\mathrm{k}-1$, dengan $\mathrm{k}$ adalah banyaknya kelas atau kelompok interval (Supardi, 2016).

Kreteria yang digunakan dengan menggunakan taraf signifikan 5\%, jika nilai X2hitung $\leq$ X2tabel maka $\mathrm{H}_{-}$Oditerima dan $\mathrm{H} \_$aditolak yang berarti sebaran data berdistribusi normal, sedangkan jika nilai X2hitung > X2 tabel maka H_Oditolak dan H_aditerima yang berarti sebaran data tidak berdistribusi normal (Sugiyono, 2016).

Adapun hipotesis yang diuji yaitu hipotesis nol (H_0 ) yang berbunyi tidak terdapat korelasi yang signifikan antara sikap ilmiah dalam belajar dengan kompetensi inti pengetahuan IPA siswa kelas V SD Gugus Kapten Kompyang Sujana Denpasar Barat Tahun Pelajaran 2017/2018.Ketentuan dari analisis product moment yang digunakan yaitu apabila hasil $r_{-}\left(x y\right.$ hitung) $>r_{-}\left(x y\right.$ tabel) maka $H_{-}$0ditolak dan hipotesis alternatif (H_a) diterima.Sebaliknya apabila hasil $r_{-}(x y$ hitung $) \leq r_{-}(x y$ tabel) maka H_0ditolak dan $H_{-} a$ diterima.Nilai $r_{-}(x y$ tabel)pada taraf signifikansi $5 \%$ adalah 0,138 sebagai pembanding.

\section{ANALISIS DAN PEMBAHASAN}

Berdasarkan hasil analisis data kompetensi inti pengetahuan IPA diketahuai bahwa rata-rata $(\bar{y})=$ $75,61, \mathrm{Xt}=97, \mathrm{Xr}=55$ dan standar deviasi $(\mathrm{s})=9,785$. Data kompetensi inti pengetahuan IPA siswa juga disajikan dalam bentuk grafik berikut.

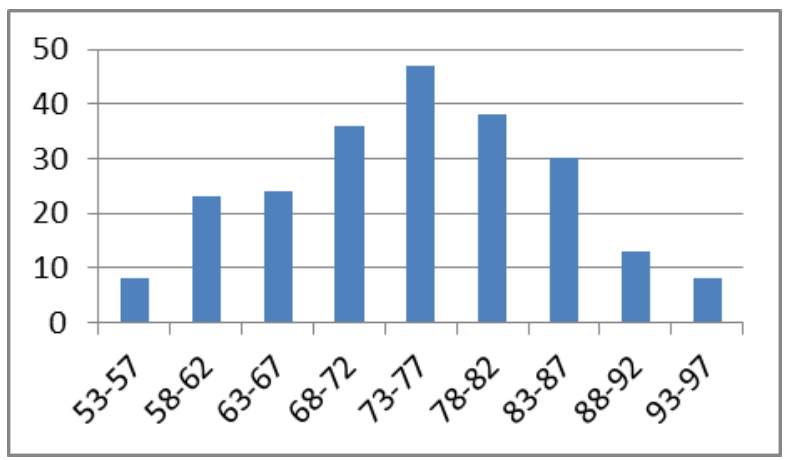

Gambar 1. Histogram Data Kompetensi Inti Pengetahuan IPA 
Berdasarkan gambar 1.tentang diagram data kompetensi inti pengetahuan IPA dapat diketahui bahwa frekuensi nilai terbanyak terdapat pada interval ke-5, selanjutnya dapat dilihat data berikut ini tentang tingkat kategori kompetensi inti pengetahuan IPA siswa SD di Gugus Kapten Kompyang Sujana, Denpasar Barat.

Tingkat perkembangan kognitif yang diperoleh anak hasilnya dikonversikan dengan cara, membandingkan angka rata-rata dengan kriteria penilaian acuan patokan (PAP) skala 5 sebagai berikut.

Tabel 1. Pedoman Konversi PAP Skala Lima tentang Tingkat Kompetensi Inti Pengetahuan IPA

\begin{tabular}{cc}
\hline Persentase Kompetensi Inti Pengetahuan IPA & Kriteria Kompetensi Inti Pengetahuan IPA \\
\hline $90-100$ & Sangat Baik \\
$80-89$ & Baik \\
$65-79$ & Cukup Baik \\
$55-64$ & Kurang Baik \\
$0-54$ & Sangat Kurang Baik \\
\hline
\end{tabular}

(Sumber: Agung, 2014)

Dari tabel 1 tentang kategori tingkat kompetensi inti pengetahuan IPA siswa diatas serta hasil dari analisis data, bahwa rerata dari kompetensi inti pengetahuan IPA siswa adalah 75,61 dan nilai tersebut berada pada nilai PAP rentang 65 - 79. Maka dapat disimpulkan bahwa kompetensi inti IPA siswa kelas V di SD Gugus Kapten Kompyang Sujana, Denpasar Barat tergolong cukup baik. Hasil uji prasyarat analisis data, diperoleh bahwa data kompetensi inti pengetahuan IPA siswa yaitu $x^{2}$ hitung $=10,92$ dan menggunakan taraf signifikansi 5\% dengan derajat kebebasan 5, maka diperoleh $x^{2}$ tabel $=11,07$.Jadi $H_{0}$ diterima yang berarti sebaran data berdistribusi normal.

Hasil analisis data sikap ilmiah dalam belajar diketahui bahwa rata-rata $(\bar{x})=77,63, \mathrm{Xt}=94, \mathrm{Xr}=$ 62 dan standar deviasi (s) = 7,573. Data sikap ilmiah dalam belajar siswa juga disajikan dalam bentuk grafik berikut.

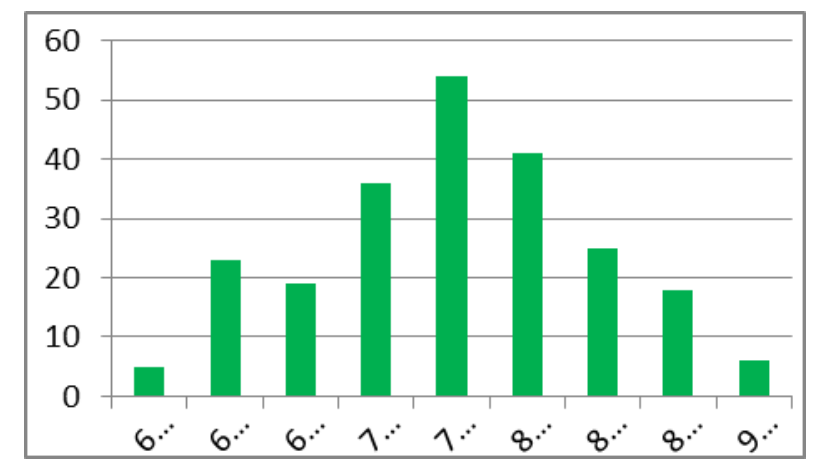

Gambar 2. Histogram Sikap Ilmiah Dalam Belajar

Berdasarkan gambar 2 tentang diagram data sikap ilmiah dalam belajar dapat diketahui bahwa frekuensi nilai terbanyak terdapat pada interval ke-5, selanjutnya dapat dilihat data berikut ini tentang tingkat kategori sikap ilmiah dalam belajar siswa SD di Gugus Kapten Kompyang Sujana, Denpasar Barat.

Tingkat perkembangan kognitif yang diperoleh anak hasilnya dikonversikan dengan cara, membandingkan angka rata-rata dengan kriteria penilaian acuan patokan (PAP) skala 5 sebagai berikut.

Tabel 2. Pedoman Konversi PAP Skala Lima tentang Tingkat Sikap Ilmiah Dalam Belajar

\begin{tabular}{cc}
\hline Persentase & Kriteria Sikap Ilmiah Dalam Belajar \\
\hline $90-100$ & Sangat Tinggi \\
$80-89$ & Tinggi \\
$65-79$ & Cukup Tinggi \\
$55-64$ & Kurang Tinggi \\
\hline
\end{tabular}


Dari tabel 2 tentang kategori tingkat sikap ilmiah dalam belajar siswa diatas serta hasil dari analisis data, bahwa rerata dari sikap ilmiah dalam belajar siswa adalah 77,63 dan nilai tersebut berada pada nilai PAP rentang 65 - 79. Maka dapat disimpulkan bahwa sikap ilmiah dalam belajar siswa kelas V SD di Gugus Kapten Kompyang Sujana, Denpasar Barat tergolong cukup tinggi.

Hasil uji prasyarat analisis data, diperoleh bahwa data sikap ilmiah dalam belajar yaitu

$x^{2}$ hitung $=2,39$ dan menggunakan taraf signifikansi 5\% dengan derajat kebebasan 5, maka diperoleh

$x^{2}$ tabel $=11,07$. Jadi $H_{0}$ diterima yang berarti sebaran data berdistribusi normal.

Setelah data diketahui berdistribusi normal, dilanjutkan dengan pengujian hipotesis penelitian.Pengujian hipoteisis yang digunakan adalah analisis product moment, untuk mengetahui korelasi antara sikap ilmiah dalam belajar dengan kompetensi inti pengetahuan IPA.Berdasarkan pada tabel penolong, maka diperoleh nilai untuk menghitung koefisien korelasi sebagai berikut.

$\sum X=17601$

$\sum X^{2}=1376779$

$\sum X Y=1317627$

$\sum Y=16952$

$\sum Y^{2}=1286850$

$\mathrm{n}=227$

Setelah mendapatkan nilai tersebut, maka nilai-nilai tersebut dimasukkan ke dalam rumus product moment sebagai berikut.

$r_{x y}=\frac{\mathrm{N} \sum \mathrm{XY}-(\mathrm{Cx})\left(\sum \mathrm{Y}\right)}{\sqrt{\left[\mathrm{N} \sum \mathrm{x}^{2}-\left(\sum \mathrm{x}\right)^{2}\right]\left[\mathrm{N} \Sigma \mathrm{Y}^{2}-\left(\sum \mathrm{Y}\right)^{2}\right]}}$

(Agung, 2016:125)

Keterangan :

$r_{x y} \quad=$ Koefisien korelasi

$\mathrm{N}=$ Jumlah subjek

$\mathrm{X}=$ Skor item

$\mathrm{Y}=$ Skor total

$\sum \mathrm{X} \quad=$ Jumlah skor item

$\sum \mathrm{Y}=$ Jumlah skor total

$\sum \mathrm{X}^{2}=$ Jumlah kuadrat skor item

$\Sigma \mathrm{Y}^{2}=$ Jumlah kuadrat skor total

Setelah dilakukan pengujian signifikansi koefisien dengan rumus product moment diperoleh hasil $r_{x y \text { hitung }}=0,202$. Untuk uji signifikansi koefisien korelasi, digunakan nilai tabel product moment (r) untuk $n=227$ pada taraf signifikansi 5\% adalah 0,138 sebagai pembanding. Maka dapat dinyatakan

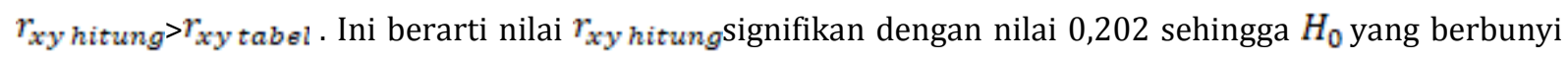
tidak terdapat korelasi yang signifikan antara sikap ilmiah dalam belajar dengan kompetensi inti pengetahuan IPA siswa kelas V SD Gugus Kapten Kompyang Sujana Denpasar Barat Tahun Pelajaran

2017/2018 ditolak, dan $H_{a}$ diterima. Hal ini menunjukkan bahwa terdapat korelasi antara sikap ilmiah dalam belajar dengan kompetensi inti pengetahuan IPA. Sedangkan arah korelasi yang diperoleh yaitu arah korelasi positif yang berarti semakin tinggi sikap ilmiah siswa dalam belajar maka semakin tinggi pula kompetensi inti pengetahuan IPA yang diperoleh siswa. 
Berdasarkan hasil analisis yang diperoleh arti $r_{x y \text { hitung }}>r_{x y \text { tabel }}$ sehingga $H_{a}$ yang berbunyi terdapat korelasi yang signifikan antara sikap ilmiah dalam belajar dengan kompetensi inti pengetahuan IPA siswa kelas V SD Gugus Kapten Kompyang Sujana Denpasar Barat Tahun Pelajaran 2017/2018 diterima.Berdasarkan uraian tersebut dapat diinterpretasi, bahwa rata-rata siswa yang mempunyai sikap ilmiah dalam belajar dapat memperoleh kompetensi inti pengetahuan IPA yang lebih tinggi daripada siswa yang belum mempunyai dan mengembangkan sikap ilmiah dalam belajar.

Interpretasi di atas dapat diartikan bahwa, semakin tinggi sikap ilmiah siswa dalam belajar membuat siswa lebih aktif dalam belajar sehingga dapat mempermudah siswa dalam menerima dan memahami materi mata pelajaran IPA yang diberikan oleh guru yang akhirnya mempengaruhi penguasaan kompetensi inti pengetahuan IPA siswa. Hal ini sesuai dengan pendapat Harso (2014) menyatakan siswa yang memiliki sikap ilmiah yang tinggi memiliki kelancaran dalam berpikir sehingga termotivasi untuk selalu berprestasi dan memiliki komitmen yang kuat untuk mencapai keberhasilan dan keunggulan.

Siswa yang memiliki kelancaran dalam berpikir tidak mengalami kesulitan dalam memahami dan menyelesaikan soal tentang mata pelajaran IPA.Keberhasilan dan keunggulan siswa dalam menguasai kompetensi inti pengetahuan IPA salah satunya tergantung pada sikap ilmiah yang dimiliki siswa dalam belajar.Sikap ilmiah dalam belajar sangat diperlukan oleh siswa karena dapat memotivasi siswa dalam kegiatan belajar.

Siswa yang mempunyai sikap ilmiah juga mempunyai kemampuan berpikir kritis, dengan kemampuan berpikir kritis siswa selalu melibatkan diri pada proses pembelajaran. Keterlibatan siswa secara langsung dalam pembelajaran dapat meningkatkan daya ingat yang kuat terhadap apa yang dipelajari. Tentunya hal tersebut dapat mempengaruhi prestasi siswa dalam pembelajaran. Hal tersebut sejalan dengan pendapat Wahyudi (2011:Vol. 1) yang menyatakan bahwa sikap ilmiah memiliki pengaruh yang signifikan dalam meningkatkan hasil belajar siswa.

Pada penelitian ini diperoleh $r_{x y \text { hitung }}=0,202$ dengan $r_{x y \text { tabel }}=0,138$ yang berarti $r_{x y \text { hitung }}>r_{x y \text { tabel }}$. Hal ini sejalan dengan penelitian Dewi (2014) mengatakan bahwa semakin tinggi skor sikap ilmiah yang dicapai siswa maka semakin tinggi pula hasil belajar yang dicapai siswa tersebut dengan hasil yang ditunjukkan melalui persamaan garis regresi $\hat{y}=71,177+0,059 X_{1}$ dengan presentase sebesar 14\% dan penelitian oleh Sihombing (2016) dengan hasil nilai koefisien determinasi adalah 0,574 yang mempunyai arti bahwa besarnya sumbangan sikap ilmiah terhadap hasil belajar kognitif siswa adalah 57,4\%.Hasil penelitian dapat disimpulkan ada korelasi positif antara sikap ilmiah dalam belajar dengan kompetensi inti pengetahuan IPA siswa kelas V SD Gugus Kapten Kompyang Sujana Denpasar Barat Tahun Pelajaran 2017/2018.

\section{KESIMPULAN}

Hasil analisis menunjukkan bahwa terdapat korelasi yang signifikan antara sikap ilmiah dalam belajar dengan kompetensi inti pengetahuan IPA siswa kelas V SD Gugus Kapten Kompyang Sujana Denpasar Barat Tahun Pelajaran 2017/2018.Kategori korelasi yang diperoleh termasuk korelasi rendah antara sikap ilmiah dalam belajar dengan kompetensi inti pengetahuan IPA.Sedangkan arah korelasi adalah positif karena nilai $r$ positif, berarti semakin tinggi sikap ilmiah dalam belajar maka semakin tinggi pula kompetensi inti pengetahuan IPA.

Berdasarkan hasil analisis diperoleh $r_{-}(x y$ hitung) $=0,202$ dengan taraf signifikan $5 \%$ dan untuk $n$ $=227$ diperoleh $r_{-}(x y$ tabel $)=0,138$ pada taraf signifikansi $5 \%$ sebagai pembanding yang berarti $r_{-}(x y$ hitung) $>r_{\_}(x y$ tabel), sehingga disimpulkan terdapat korelasi yang signifikan antara sikap ilmiah dalam belajar dengan kompetensi inti pengetahuan IPA siswa kelas V SD Gugus Kapten Kompyang Sujana Denpasar Barat Tahun Pelajaran 2017/2018.

Berdasarkan uraian tersebut diintrerpretasikan, maka ini berarti rata-rata siswa yang mempunyai sikap ilmiah dalam belajar dapat memperoleh kompetensi inti pengetahuan IPA yang lebih tinggi daripada siswa yang belum mempunyai dan mengembangkan sikap ilmiah dalam belajar. Jadi dapat disimpulkan bahwa korelasi antara sikap ilmiah dalam belajar dengan kompetensi inti pengetahuan IPA memiliki korelasi dengan arah positif pada kategori rendah.

Berdasarkan hasil penelitian ini, maka dapat diajukan beberapa saran guna peningkatan kualitas pembelajaran yaitu:

Kepada guru, Berdasarkan temuan penelitian yang diperoleh, disarankan kepada guru agar lebih berinovasi dalam pembelajaran guna meningkatkan sikap ilmiah dalam belajar pada kompetensi inti pengetahuan IPA. Guru sebaiknya dapat menumbuhkan dan mengembangkan sikap ilmiah yang ada pada 
diri siswa. Melalui hal tersebut nantinya siswa lebih aktif dan berprestasi dalam setiap kegiatan pembelajaran.

Kepada sekolah, Hasil penelitian ini diharapkan dapat menjadi pedoman kepala sekolah untuk mengarahkan guru dalam menumbuhkan dan mengembangkan sikap ilmiah dalam belajar guna mengoptimalkan kompetensi siswa khususnya dalam kompetensi inti pengetahuan IPA sehingga mutu sekolah menjadi meningkat. Kepada peneliti lain, hendaknya hasil penelitian ini dapat dijadikan kajian penelitian relevan serta peneliti lain diharapkan melakukan penelitian lebih lanjut dan semoga penelitian ini bermanfaat bagi seluruh elemen masyarakat yang menggunakan penelitian ini.

\section{DAFTAR PUSTAKA}

Agung, A.A. Gede. 2016. Statistika Dasar untuk Pendidikan. Yogyakarta: CV. Budi Utama.

BSNP, 2006.Standar Isi untuk Satuan Pendidikan Dasar dan Menengah. Jakarta: BSNP.

Bundu, Patta. 2006. Penilaian Keterampilan Proses dan Sikap Ilmiah dalam Pembelajaran Sains di SD. Jakarta: Depdiknas.

Dewi, I Gst. A. Wulan Kartika. 2014. "Hubungan Sikap Ilmiah dan Motivasi Berprestasi dengan Hasil Belajar IPA Pada Siswa Kelas V SD”. Jurusan Pendidikan Dasar, Universitas Penidikan Ganesha, Volume 2, Nomor 1. Tersedia pada http://ejournal.undiksha.ac.id/index.php//JJPGSD/article/ download/259(diakses tanggal 17 Januari 2018).

Harso, A. 2014."Pengaruh Model Pembelajaran Heuristik Vee terhadap Pemahaman Konsep Fisika dan Sikap Ilmiah Siswa Kelas X SMA Negeri 2 Langke Rembong Tahun Pelajaran 2013/2014".Program Studi Pendidikan IPA, Program Pasca Sarjana, Universitas Penidikan Ganesha, Volume 4, Nomor 1. Tersedia pada http://pasca.undiksha.ac.id/ejournal/index.php/jurnal_ipa/article/view/138 (diakses tanggal 2 Januari 2018).

Samatowa, Usman. 2011. Pembelajaran IPA di Sekolah Dasar. Jakarta Barat: Indeks.

Sihombing, Chintani. 2016. "Hubungan Keterampilan Metakognitif dan Sikap Ilmiah dengan Hasil Belajar Biologi Siswa Kelas XI SMAN se-Kabupaten Tapanuli Utara”, Prodi Pendidikan Guru Sekolah Dasar, Universitas Efarina, Volume 2, Nomor 1. Tersedia pada http://digilib.unimed.ac.id/5293/ (diakses tanggal 17 Januari 2018).

Slameto. 2010. Belajar \& Faktor-Faktor yang Mempengaruhi. Jakarta: PT. Rineka Cipta.

Sugiartana, Md. Slamet. 2013. "Penerapan Model TGT untuk Meningkatkan Hasil Belajar IPA dan Sikap Ilmiah Siswa Kelas VB SD Negeri 3 Banjar Jawa”, Jurusan Pendidikan Guru Sekolah Dasar, Universitas Pendidikan Ganesha, Volume 1, Nomor 1. Tersedia pada https://ejournal.undiksha.ac.id/index.php/JJPGSD/article/view/871(diakses tanggal 3 Januari 2018)

Sugiyono. 2016. Metode Penelitian Pendidikan (Pendekatan Kuantitatif, Kualitatif dan R\&D). Bandung: Alfabeta.

Supardi, 2016.Aplikasi Statistika dalam Penelitian Edisi Revisi Konsep Statistika yang Lebih Komprehensif. Jakarta Selatan: Change Publication.

Suryani, Iis. 2016. "Pengembangan Instrumen Penilaian Sikap Ilmiah pada Pembelajaran dengan Model Latihan Penelitian di Sekolah Dasar", Jurusan Pendidikan Guru Sekolah Dasar, Universitas Pendidikan Indonesia, Volume 2, Nomor 2 (hlm. 217-227). Tersedia pada http://ejournal.upi.edu/index.php/pedadidaktika/article/view/5152(diakses tanggal 3 Januari 2018).

Susanto, Ahmad. 2015. Teori Belajar dan Pembelajaran di SD. Jakarta: Prenadamedia Group. 
Wahyudi. 2016. "Analisis Kontribusi Sikap Ilmiah, Motivasi Belajar dan Kemandirian Belajar Terhadap Prestasi Belajar Mahasiswa Prodi Pendidikan Fisika STKIP PGRI Pontianak", Prodi Pendidikan Fisika, STKIP PGRI Pontianak, Volume 1, Nomor 2 (hlm 20-31). Tersedia pada http://media.neliti.com (diakses tanggal 3 Januaro 2018). 